\title{
Association of paternal age at birth and the risk of breast cancer in offspring: a case control study
}

\author{
Ji-Yeob Choi ${ }^{1}$, Kyoung-Mu Lee ${ }^{1}$, Sue Kyung Park ${ }^{1}$, Dong-Young Noh ${ }^{2}$, Sei- \\ Hyun Ahn' ${ }^{3}$, Keun-Young Yoo ${ }^{1}$ and Daehee Kang*1,4
}

\begin{abstract}
Address: ${ }^{1}$ Department of Preventive Medicine, Seoul National University College of Medicine, 28 Yongon-Dong Chongno-Gu, Seoul 110-799 Korea, ${ }^{2}$ Department of General Surgery, Seoul National University College of Medicine, 28 Yongon-Dong Chongno-Gu, Seoul 110-799 Korea, ${ }^{3}$ Department of General Surgery, Ulsan University College of Medicine, 388-1 Pungnap-2dong Songpa-gu, Seoul 138-736, Korea and ${ }^{4}$ Cancer Research Institute, Seoul National University College of Medicine, 28 Yongon-Dong Chongno-Gu, Seoul 110-799 Korea
\end{abstract}

Email: Ji-Yeob Choi - miso77@snu.ac.kr; Kyoung-Mu Lee - kmlee92@snu.ac.kr; Sue Kyung Park - suepark@kku.ac.kr; DongYoung Noh - dynoh@plaza.snu.ac.kr; Sei-Hyun Ahn - ahnsh@amc.seoul.kr; Keun-Young Yoo - kyyoo@plaza.snu.ac.kr;

Daehee Kang* - dhkang@snu.ac.kr

* Corresponding author

Published: 3I October 2005

BMC Cancer 2005, 5:143 doi:10.1 |86/|47|-2407-5-143
Received: 08 July 2005

Accepted: 31 October 2005

This article is available from: http://www.biomedcentral.com/I47I-2407/5/I43

(c) 2005 Choi et al; licensee BioMed Central Ltd.

This is an Open Access article distributed under the terms of the Creative Commons Attribution License (http://creativecommons.org/licenses/by/2.0), which permits unrestricted use, distribution, and reproduction in any medium, provided the original work is properly cited.

\begin{abstract}
Background: Older paternal age may increase the germ cell mutation rate in the offspring. Maternal age may also mediate in utero exposure to pregnancy hormones in the offspring. To evaluate the association between paternal and maternal age at birth with the risk of breast cancer in female offspring, a case-control study was conducted in Korea.
\end{abstract}

Methods: Histologically confirmed breast cancer cases $(n=I, 0 I I)$ and controls $(n=I, 0 I I)$ with no present or previous history of cancer, matched on year of birth and menopausal status, were selected from several teaching hospitals and community in Seoul during 1995-2003. Information on paternal and maternal ages and other factors was collected by interviewed questionnaire. Odds ratio (OR) and $95 \%$ confidence interval $(95 \% \mathrm{Cl})$ were estimated by unconditional logistic regression model adjusting for family history of breast cancer in $1^{\text {st }}$ or $2^{\text {nd }}$ degree relatives, and lifetime estrogen exposure duration.

Results: The risk of breast cancer significantly increased as the paternal age increased ( $\mathrm{p}$ for trend $=0.025$ ). The association was stronger after controlling for maternal age; women whose fathers were aged $\geq 40$ years at their birth had I.6-fold increased risk of breast cancer compared with fathers aged $<30$ years. This association was profound in breast cancer cases in premenopausal women $(\mathrm{OR}=1.9,95 \% \mathrm{Cl}=1.12-3.26$, for paternal aged $\geq 40$ vs. $<30)$ ( $\mathrm{p}$ for trend $=0.03 \mathrm{I})$. Although the risk of breast cancer increased as maternal age increased up to the intermediate, and then reduced; the risks in women whose mother were aged $25-29,30-34$, and $\geq 35 \mathrm{yrs}$ at birth compared to women whose mothers were aged $<25$ years, were $1.2,1.4$, and 0.8 , respectively, the trend was not significant ( $\mathrm{p}$ for trend $\mathbf{0 . 9 9 8}$ ).

Conclusion: These findings suggest that older paternal age increases the risk of breast cancer in their female offspring. 


\section{Background}

There have been growing evidences that prenatal factors may play an important role in determining breast cancer risk in adult life. These factors are hypothesized to affect breast cancer risk by altering the hormonal environment of the developing fetus [1], or by affecting the cumulative frequency of germ cell mutations $[2,3]$.

A numbers of epidemiologic research have suggested that older parental ages may influence risk for subsequent development of breast cancer later in their lives. Several studies found a slightly increased risk of breast cancer for women whose mothers were older [4-11], but not all [1225]. Similarly, there have been conflicting results with regard to breast cancer risk according to paternal age $[4,5,8,9,13,16,18,20,24,25]$. Recently, Innes et al [7] suggested that there was a positive trend in risk of breast cancer with increasing paternal age in young women.

These inconsistent results from previous studies might be due to several factors; small numbers of breast cancer cases, subject selection (e.g., age at diagnosis, different ethnicity), improper adjustment of covariates and paternal and maternal ages mutually, other study design issue (no information on known risk factors).

There is a trend toward higher paternal and maternal ages predominantly in Korea as well as in developed countries [26]. To our knowledge no studies published to date have specifically addressed the association between paternal and maternal ages and breast cancer risk in Asian women. We evaluate the independent effect of both paternal and maternal ages at birth on the risk of breast cancer of their daughters in a large case-control study in Korean.

\section{Methods}

The cases consisted of a consecutive series of breast cancer patients admitted to three teaching hospitals located in Seoul, Korea (SNUH, Borame, and Asan) between 1995 and 2003. The control subjects consisted of non-cancer patients admitted to the same hospitals as the cases in the same period and of healthy women who participated in the community health screening program provided by a teaching hospital located in Seoul (EWUMC) in 2003. The study design was approved by the Institutional Review Board of Seoul National University Hospital, and the subjects provided their informed consents prior to participation in the study.

Of 1,999 histologically confirmed incident breast cancer patients and 1,548 cancer-free controls, 1,709 breast cancer cases and 1,412 cancer-free controls were eligible after exclusion of subjects with previous history of cancer or previous history of hysterectomy and/or oophorectomy due to cervical, ovarian cancer or its precursors. The con- trol group consisted of 577 healthy women and of 835 hospital controls with non-cancerous diseases including infection or stone of gall bladder/bile duct (26\%), benign breast disease (e.g. fibroadenomas, fibrocystic disease, mastitis, etc.) (17\%), acute appendicitis (14\%), hemorrhoid (8\%), hernia/perforation (7\%), lipoma (2\%), and the others $(26 \%$ included liver injury, cellulitis, chronic bowl disease, benign vascular disease, ulcer, etc.). The proportion of atypical hyperplasia was estimated less than $0.2 \%$ among benign breast disease in Korean [27].

Information on demographic characteristics, current and previous residence, education, marital status, family history of breast cancer in the $1^{\text {st }}$ and $2^{\text {nd }}$ degree relatives, reproductive and menstrual factors, life-style habits including cigarette smoking, alcohol consumption, oral contraceptive use, and hormone replacement therapy was collected by trained interviewers using a structured questionnaire.

After exclusion of subjects with missing value of either maternal or paternal age ( $n=185$ in cases; $n=320$ in controls), cases were frequency matched to controls by 10year of birth group (before 1930, 1930-1939, 19401949, 1950-1959, 1960-1969, after 1970) and menopausal status. The final study population consisted of 1,011 cases and 1,011 controls. The distribution of matched controls was similar to that of unmatched controls (missing either paternal or maternal age) with regard to age, family history of breast cancer in $1^{\text {st }}$ or $2^{\text {nd }}$ degree relatives, and lifetime estrogen exposure duration. Risk factors profiles were not different between hospital and healthy community controls [28]; although community controls were older than hospital controls, the distributions of most known risk factors (e.g., education, family history of breast cancer in $1^{\text {st }}$ and $2^{\text {nd }}$ degree relatives) were similar. The means of paternal and maternal ages at birth were not significantly different between hospital and community controls (32.7 vs. 32.1 in paternal age, $\mathrm{p}=$ $0.222 ; 28.3$ vs. 28.4 in maternal age, $\mathrm{p}=0.807$ examined by $t$-test). The means of paternal and maternal age at birth of patients with benign breast disease among controls were also different from neither hospital controls nor overall controls (data not shown). Although eighty-seven percent of hospital controls and $97 \%$ of community controls came from the same catchment areas (Seoul and suburbs), other demographical characteristics (e.g., age, paternal age, maternal age) were similar between hospital and community controls. Thus, the final statistical analyses were done by adjusting for all significant covariates identified from the initial analysis.

The associations between factors of interest and breast cancer risk were estimated as odds ratios (ORs) and 95\% confidence intervals (CIs) by unconditional logistic 
Table I: Selected characteristics for I,0 I I breast cancer cases and I,0 I I controls matched by year of birth and menopausal status

\begin{tabular}{|c|c|c|c|}
\hline \multirow[t]{2}{*}{ Risk factor } & \multirow{2}{*}{$\begin{array}{l}\text { Cases (\%) } \\
n=1,011\end{array}$} & \multirow{2}{*}{$\begin{array}{l}\text { Control (\%) } \\
n=1,011\end{array}$} & \multirow[t]{2}{*}{ OR $(95 \% \mathrm{Cl})$} \\
\hline & & & \\
\hline Age (yrs) (mean \pm SD) & $47.7 \pm 10.9$ & $47.7 \pm 11.7$ & $P=0.984^{*}$ \\
\hline \multicolumn{4}{|l|}{ Education } \\
\hline Under or at middle school & $3 \mid 5(3 \mid .3)$ & $319(31.7)$ & 1.0 \\
\hline At high school & $378(37.5)$ & $407(40.5)$ & $1.0(0.80-1.24)$ \\
\hline At or over college & $315(31.3)$ & $280(27.8)$ & $1.2(0.98-1.57)$ \\
\hline \multicolumn{4}{|l|}{ FHBC $\ddagger$} \\
\hline No & $937(92.7)$ & $976(96.5)$ & 1.0 \\
\hline Yes & $74(7.3)$ & $35(3.5)$ & $2.2(1.47-3.38)$ \\
\hline \multicolumn{4}{|c|}{ Age at FFTP $\ddagger$ (yrs) or nulliparity } \\
\hline$<25$ & $325(32.2)$ & 349 (34.9) & 1.0 \\
\hline $25-29$ & $477(47.3)$ & $471(47.1)$ & I.I $(0.92-1.38)$ \\
\hline$\geq 30$ or nulliparity & $206(20.4)$ & $181(18.1)$ & $1.3(1.04-1.76)$ \\
\hline$P$ for trend & & & $p=0.027$ \\
\hline LEE $\ddagger(y r s)($ mean \pm SD) & $29.1 \pm 6.9$ & $28.3 \pm 7.4$ & $1.2(I .05-1.4 I)^{\dagger}$ \\
\hline \multicolumn{4}{|l|}{ BMI $\left(\mathrm{kg} / \mathrm{m}^{2}\right)$} \\
\hline$<25.0$ & $748(74.4)$ & $769(76.8)$ & 1.0 \\
\hline $25.0-29.9$ & $227(22.6)$ & $216(21.6)$ & $\mathrm{I} .0(0.84-1.29)$ \\
\hline$\geq 30.0$ & $31(3.1)$ & $16(1.6)$ & $2.0(1.07-3.78)$ \\
\hline \multicolumn{4}{|l|}{ Smoking status } \\
\hline Nonsmoker & $933(92.4)$ & $943(93.4)$ & 1.0 \\
\hline Smoker & $77(7.6)$ & $67(6.6)$ & $1.2(0.85-1.70)$ \\
\hline \multicolumn{4}{|l|}{ Alcohol drinking } \\
\hline$<1 /$ month & $756(74.8)$ & $709(72.3)$ & 1.0 \\
\hline I-3/month & $178(17.6)$ & $211(21.5)$ & $0.8(0.64-1.02)$ \\
\hline$\geq \mathrm{l} /$ week & $77(7.6)$ & $61(6.2)$ & $1.2(0.86-1.76)$ \\
\hline
\end{tabular}

OR of case vs. matched control adjusted for family history of breast cancer in Ist $^{\text {st }} 2^{\text {nd }}$ degree relatives and lifetime estrogen exposure duration *P value by student $t$ test, TOR per 10 year, $¥ F H B C$, Family history of breast cancer in Ist ${ }^{\text {s }} 2^{\text {nd }}$ degree relatives; FFTP, first full-term pregnancy; LEE, lifetime estrogen exposure duration

regression model adjusting for family history of breast cancer in $1^{\text {st }}$ or $2^{\text {nd }}$ degree relatives (yes/no), and lifetime estrogen exposure duration (yrs) (presenting the number of years of exposure to menstrual cycles, which is calculated according to the age at menarche and age at interview for premenopausal women and age at menarche and age at menopause for postmenopausal women), which were identified as the significant covariates ( $\mathrm{p}$ value < 0.05 ) in the initial analysis. The variables included in the logistic model were selected among age (yrs), education (under or at middle school, at high school, at or over college), family history of breast cancer in $1^{\text {st }}$ or $2^{\text {nd }}$ degree relatives (yes/no), lifetime estrogen exposure duration (yrs), age at full-term pregnancy or nulliparous ( $<25 \mathrm{yrs}$, $25-29$ yrs, $\geq 30$ yrs or nulliparity), cigarette smoking (smoked at least 400 cigarettes/lifetime, yes/no), frequency of alcohol consumption $(<1 /$ month, $1-3 /$ month, $\geq 1$ /week) and body mass index (BMI) $\left(<25.0 \mathrm{~kg} / \mathrm{m}^{2}\right.$, $25.0-30.0 \mathrm{~kg} / \mathrm{m}^{2}, \geq 30.0 \mathrm{~kg} / \mathrm{m}^{2}$ ). Only the adjusted estimates were reported in the results because the change in the $\beta$ coefficient for any level of the paternal and maternal ages relative to the referent was less than $20 \%$ between unadjusted estimates and those adjusted for family history of breast cancer in $1^{\text {st }}$ or $2^{\text {nd }}$ degree relatives (yes/no), and lifetime estrogen exposure duration (yrs). Tests for trend in risk were conducted by treating categorical values as a continuous variable.

Paternal and maternal ages of subjects at birth were first compared using $t$-test and the estimates of odds ratios (ORs) with adjustment for other covariates were obtained using unconditional logistic regression analysis. We classified subjects into four groups according to paternal age at birth $(<30,30-34,35-39, \geq 40)$ and maternal age at birth $(<25,25-29,30-34, \geq 35)$. Separate analysis was conducted with and without the other paternal or maternal age mutually adjusting. To evaluate the independent effect of paternal and maternal ages, the ORs were calculated after stratified by the each paternal and maternal age group. Finally, we assessed the association of paternal and maternal ages at birth with breast cancer after stratified by menopausal status. All statistical analyses were performed using STATA version 8.0 (Stata corporation, College Station, TX).

\section{Results}

Family history of breast cancer in $1^{\text {st }}$ and $2^{\text {nd }}$ degree relatives $(\mathrm{OR}=2.2,95 \% \mathrm{CI}=1.47-3.38)$, lifetime estrogen 
Table 2: Association between paternal and maternal ages at birth and risk of breast cancer in daughters

\begin{tabular}{|c|c|c|c|c|}
\hline $\begin{array}{l}\text { Age at birth of the } \\
\text { subjects (yrs) }\end{array}$ & Cases (\%) & Controls (\%) & OR $(95 \% \mathrm{CI})^{\prime}$ & OR $(95 \% \mathrm{Cl})^{2}$ \\
\hline \multicolumn{5}{|l|}{ Paternal age } \\
\hline Mean \pm SD & $33.1 \pm 7.5$ & $32.5 \pm 7.2$ & $1.1(1.00-1.28)^{\dagger}$ & \\
\hline$<30$ & $362(35.8)$ & $400(39.6)$ & 1.0 & 1.0 \\
\hline $30-34$ & $266(26.3)$ & $26 \mathrm{I}(25.8)$ & $1.2(0.92-1.45)$ & $1.0(0.79-1.34)$ \\
\hline $35-39$ & $169(16.7)$ & $174(17.2)$ & I.I (0.83-I.40) & $1.0(0.71-1.39)$ \\
\hline$\geq 40$ & $214(21.2)$ & $176(17.4)$ & $1.4(1.07-1.76)$ & $1.6(1.04-2.32)$ \\
\hline$P$ for trend & & & 0.025 & 0.090 \\
\hline \multicolumn{5}{|l|}{ Maternal age } \\
\hline Mean \pm SD & $28.7 \pm 6.4$ & $28.3 \pm 6.5$ & I.I $(0.97-1.28)^{\dagger}$ & \\
\hline$<25$ & $285(28.2)$ & $330(32.6)$ & 1.0 & 1.0 \\
\hline $25-29$ & $302(29.9)$ & $297(29.4)$ & I.2(0.97-I.54) & $1.2(0.95-1.56)$ \\
\hline $30-34$ & $237(23.4)$ & $192(19.0)$ & $1.5(1.18-1.95)$ & $1.4(1.00-1.94)$ \\
\hline$\geq 35$ & $187(18.5)$ & $192(19.0)$ & I.I (0.88-I.48) & $0.8(0.55-1.27)$ \\
\hline$P$ for trend & & & 0.079 & 0.998 \\
\hline
\end{tabular}

'OR adjusted for family history of breast cancer in $\left.\right|^{\text {st }}$ or $2^{\text {nd }}$ degree relatives and lifetime estrogen exposure duration

${ }^{2} \mathrm{OR}$ adjusted for maternal age or paternal age (mutual parental age, categorical value) in addition to the variables in the model I tOR per 10 year

exposure duration (per 10 years) $(\mathrm{OR}=1.2,95 \% \mathrm{CI}=$ $1.05-1.41), \geq 30$ age at first full-term pregnancy or nulliparity $(\mathrm{OR}=1.3,95 \% \mathrm{CI}=1.04-1.76)$ and $\mathrm{BMI} \geq 30 \mathrm{~kg} /$ $\mathrm{m}^{2}(\mathrm{OR}=2.0,95 \% \mathrm{CI}=1.07-3.78)$ increased the risk of breast cancer significantly after adjusting for family history of breast cancer in $1^{\text {st }}$ and $2^{\text {nd }}$ degree relatives, and lifetime estrogen exposure duration (Table 1).

The mean of paternal age at birth was significantly different between cases and controls (33.1 yrs vs. 32.5 yrs; OR $=1.1,95 \% \mathrm{CI}=1.00-1.28$ per $10 \mathrm{yrs})$, however, the mean of maternal age was not ( 28.7 yrs vs. 28.3 yrs; $\mathrm{OR}=1.1$, $95 \% \mathrm{CI}=0.97-1.28$ per $10 \mathrm{yrs}$ ) (Table 2 ). The risk of breast cancer showed a significantly increased as paternal age at birth increased ( $p$ for trend $=0.025$ ). The association of paternal age with the risk of breast cancer was pronounced after controlling for maternal age; women whose fathers were aged $30-34,35-39$, and $\geq 40$ yrs at their births, had 1.0, 1.0, and 1.6-fold increased risk of breast cancer compared with women whose fathers were aged $<30$ years, respectively. The risk of breast cancer increased as maternal age increased up to the intermediate, and then reduced; the risks in women whose mother were aged 25$29,30-34$, and $\geq 35$ yrs at birth compared to women whose mothers were aged $<25$ years, were $1.2,1.4$, and 0.8 , respectively (Table 2 ). The most remarkable risk of breast cancer was observed for women with higher paternal age ( $\geq 40 \mathrm{yrs}$ ) and intermediate maternal age (30-34 yrs) compared to women with lowest paternal ( $<30 \mathrm{yrs})$ and maternal ages $(<25 \mathrm{yrs})(\mathrm{OR}=2.8,95 \% \mathrm{CI}=1.74-$ 4.62) (Table 3).

When the association was evaluated after stratified by menopausal status, the association of paternal age at birth in breast cancer was stronger in premenopausal women. Women whose fathers were aged 30-34, 35-39 and $\geq 40$ years at their birth had 1.1, 1.2 and 1.9-fold increased risk of breast cancer compared with women whose fathers were aged $<30$ years, respectively ( $p$ for trend $=0.031$ ). In contrast with paternal age, there was no significant trend between maternal age at birth and risk of breast cancer in premenopausal women ( $\mathrm{p}$ for trend $=0.361$ ) (Table 4$)$.

\section{Discussion}

The results of the present study suggested that older paternal age at the time of a child's birth was associated with an increased risk of breast cancer in female offspring, which was enhanced after controlling maternal age. The effect appears to be stronger in premenopausal women. The results also suggested that there was no consistent pattern of association between maternal age at birth and risk of breast cancer although the risk increased up to women with mothers aged $30-34$ years old and then reduced in women with maternal age older than 35 years old.

The mean age at first full-term pregnancy was 22.0 years old in marriage cohort before 1980 while 27.3 years old in the cohort of 2000-2003 in Korea [29], which shows that the age at first full-term pregnancy became progressively older in younger age groups. This study also found that the paternal and maternal age were significantly higher in the subjects born after 1950 than in those before 1950 for both case and control groups.

The results of previous studies of the relationships of the risk of breast cancer with paternal and maternal ages are summarized in Table 5 and these are not consistent. Four studies indicating that there was a increasing trend of the 
Table 3: OR $(95 \% \mathrm{Cl})$ of combined effect of paternal age and maternal ages on risk of breast cancer [cases/controls]

\begin{tabular}{|c|c|c|c|c|}
\hline \multirow[t]{2}{*}{ Paternal age (yrs) } & \multicolumn{4}{|c|}{ Maternal age (yrs) } \\
\hline & $<25$ & $25-29$ & $30-34$ & $\geq 35$ \\
\hline$<30$ & $\begin{array}{c}1.0 \\
{[230 / 273]}\end{array}$ & $\begin{array}{c}1.3(0.97-1.81) \\
{[122 / 116]}\end{array}$ & $\begin{array}{c}\text { I.I }(0.45-2.86) \\
{[9 / 10]}\end{array}$ & $\begin{array}{c}\text { I.I }(0.07-17.69) \\
{[1 / 1]}\end{array}$ \\
\hline $30-34$ & $\begin{array}{c}1.2(0.76-1.87) \\
{[46 / 47]}\end{array}$ & $\begin{array}{c}1.3(0.96-1.76) \\
{[132 / 127]}\end{array}$ & $\begin{array}{c}1.3(0.91-1.89) \\
{[81 / 79]}\end{array}$ & $\begin{array}{c}\text { I.I }(0.38-2.97) \\
{[7 / 8]}\end{array}$ \\
\hline $35-39$ & $\begin{array}{c}1.6(0.55-4.8 I) \\
{[8 / 6]}\end{array}$ & $\begin{array}{c}\text { I.I }(0.67-1.70) \\
{[4 \mid / 46]}\end{array}$ & $\begin{array}{c}1.4(1.00-2.07) \\
{[83 / 74]}\end{array}$ & $\begin{array}{c}0.9(0.55-1.42) \\
{[37 / 48]}\end{array}$ \\
\hline$\geq \mathbf{4 0}$ & $\begin{array}{c}0.3(0.04-3.07) \\
{[1 / 4]}\end{array}$ & $\begin{array}{c}1.2(0.43-3.60) \\
{[7 / 8]}\end{array}$ & $\begin{array}{c}2.8(1.74-4.62) \\
{[64 / 29]}\end{array}$ & $\begin{array}{c}1.3(0.96-1.75) \\
{[142 / 135]}\end{array}$ \\
\hline
\end{tabular}

OR adjusted for family history of breast cancer in $1^{\text {st }}$ or $2^{\text {nd }}$ degree relatives and lifetime estrogen exposure duration

risk of breast cancer in women having older father, were consisted with the present study [5,7-9]. A number of previous studies found no statistically significant association between paternal age and the risk of breast cancer in population-based large scale studies. Most of negative studies did not adjust known risk factors for breast cancer (i. e., family history of breast cancer in $1^{\text {st }}$ and $2^{\text {nd }}$ degree relatives and reproductive factors). In contrast, Hodgson et al [5] showed that there was a positive association between breast cancer and paternal age in African-American only. Innes et al [7] and Le Marchand et al [9] also reported a significant linear trend in breast caner risk with paternal age only in young cancer cases.

Most previous studies showed that maternal age was not associated with breast cancer risk in white women. However, the finding of this study that the breast cancer risk increased with increasing maternal age up to the intermediate (30-34 years old), then reduced for older than 35 years old, is consistent with previous epidemiological studies [5,11-13,24,30]. Experimental evidences also support the association between maternal age and estrogen level during pregnancy [31-33]. Panagiotopoulou et al [32] showed the inverse U-shaped relationship of maternal age to estrogen levels; there was a peak of estrogen levels in the intermediate then there was a reduction in estrogen levels with maternal age. This pattern that maternal age was not linear relationship with estradiol level during pregnancy and/or generally not in a dose-dependent gradient with age was observed among other recent studies $[31,33]$. These results supported that subjects whose mothers were oldest at the time of birth were not in the highest risk group in this study and it may be biologically relevant because there is a perimenopausal reduction in estrogens.

With regard to menopausal status, most previous results between the risk of breast cancer and maternal age including ours are inconsistent $[6,7,9,22]$. Potential reasons for inconsistent association between maternal age and breast cancer risk include differences in other maternal factors (i.e., maternal diet, pregnancy complication, and maternal reproductive history), covariates adjusted, or ethnicity.

Data published so far shows that maternal and paternal ageing may affect offspring by different mechanisms. Higher concentration of estrogen in utero could create a fertile soil for cancer initiation with regard to maternal age [1]. There is some evidence that high prenatal estrogen level affects the morphology of the mammary gland (i.e., the number of ductal branching, the density of terminal end buds). An increased number of epithelial and stromal cells offer more targets for carcinogens and greater probability for genetic/epigenetic events that affect the susceptibility of the breast cancer [34]. Higher paternal age has been implicated to be responsible for increases in chromosomal aberrations and genetic disorders [35], of which the risk increases with paternal age, but maternal age has little or no effect on the risk after controlling for paternal age [3]. Spermatogomia undergo continuous cell divisions throughout the lifetime of the adult male, while oocytes undergo only one cell division between puberty and fertilization $[2,3]$. This difference may provide a greater opportunity for germ cells of the father to experience errors of DNA replication in regard to delayed parenthood. Furthermore, the ability to respond to mutagens with germ-cell apoptosis in order to avoid genetically altered spermatozoa decreased with paternal age [36], while oocytes have an efficient DNA repair system which is independent of maternal age [37].

Although maternal and paternal ages were correlated, we were able to ascribe the risk of breast cancer to the paternal age independent on maternal age. There are, however, several issues in the present results to consider whether the observed effects can be due to confounding or bias. First, potential selection bias because offspring with higher socioeconomic status may have detected their breast cancer earlier than those with lower socioeconomic 
Table 4: Association between parental ages at birth and risk of breast cancer in daughters after stratified by menopause status

\begin{tabular}{|c|c|c|c|c|}
\hline $\begin{array}{l}\text { Age at birth of the } \\
\text { subjects (yrs) }\end{array}$ & Cases (\%) & Controls (\%) & OR $(95 \% \mathrm{CI})^{\prime}$ & OR $(95 \% \mathrm{Cl})^{2}$ \\
\hline \multicolumn{5}{|l|}{ Premenopause } \\
\hline Mean \pm SD & $33.7 \pm 7.0$ & $32.9 \pm 6.6$ & $1.16(0.98-1.38)^{\dagger}$ & \\
\hline$<30$ & $183(31.6)$ & $210(36.3)$ & 1.0 & 1.0 \\
\hline $30-34$ & $162(28.0)$ & $161(27.8)$ & I.I (0.85-I.54) & I.I (0.76-I.50) \\
\hline $35-39$ & $108(18.7)$ & $105(18.1)$ & I.I (0.82-1.60) & I.2(0.77-I.85) \\
\hline$\geq 40$ & $126(21.8)$ & $103(17.8)$ & $1.4(1.00-1.93)$ & $1.9(1.12-3.26)$ \\
\hline P for trend & & & 0.062 & 0.031 \\
\hline \multicolumn{5}{|l|}{ Maternal age } \\
\hline Mean \pm SD & $29.1 \pm 5.8$ & $28.8 \pm 6.1$ & $1.06(0.87-1.29)^{\dagger}$ & \\
\hline$<25$ & $133(23.0)$ & $159(27.5)$ & 1.0 & 1.0 \\
\hline $25-29$ & $194(33.5)$ & $187(32.3)$ & $1.3(0.93-1.73)$ & $1.2(0.86-1.70)$ \\
\hline $30-34$ & $147(25.4)$ & $120(20.7)$ & $1.5(1.06-2.07)$ & $1.2(0.78-1.88)$ \\
\hline$\geq 35$ & $105(18.1)$ & $113(19.5)$ & I.I (0.76-I.55) & $0.7(0.38-1.15)$ \\
\hline$P$ for trend & & & 0.363 & 0.361 \\
\hline \multicolumn{5}{|l|}{ Postmenopause } \\
\hline \multicolumn{5}{|l|}{ Paternal age } \\
\hline Mean \pm SD & $32.2 \pm 8.1$ & $31.8 \pm 8.0$ & I.II $(0.94-1.32)^{\dagger}$ & \\
\hline$<30$ & $179(4 \mid .4)$ & $190(44.0)$ & 1.0 & 1.0 \\
\hline $30-34$ & $104(24.1)$ & $100(23.2)$ & $1.2(0.82-1.65)$ & $1.0(0.66-1.48)$ \\
\hline $35-39$ & $61(14.1)$ & $69(16.0)$ & $1.0(0.65-1.49)$ & $0.8(0.47-1.35)$ \\
\hline$\geq 40$ & $88(20.4)$ & $73(16.9)$ & $1.4(0.94-2.03)$ & $1.2(0.66-2.29)$ \\
\hline P for trend & & & 0.173 & 0.804 \\
\hline \multicolumn{5}{|l|}{ Maternal age } \\
\hline Mean \pm SD & $28.2 \pm 7.1$ & $27.7 \pm 6.9$ & $1.16(0.95-1.41)^{\dagger}$ & \\
\hline$<25$ & $152(35.2)$ & $17 \mid(39.6)$ & 1.0 & 1.0 \\
\hline $25-29$ & $108(25.0)$ & $110(25.5)$ & I.I (0.80-1.60) & $1.2(0.80-2.29)$ \\
\hline $30-34$ & $90(20.8)$ & $72(16.7)$ & $1.6(1.05-2.31)$ & $1.6(0.97-2.69)$ \\
\hline$\geq 35$ & $82(19.0)$ & 79 (18.3) & $1.2(0.82-1.78)$ & I.I (0.58-2.03) \\
\hline$P$ for trend & & & 0.112 & 0.415 \\
\hline
\end{tabular}

IOR adjusted for family history of breast cancer in $\left.\right|^{\text {st }}$ or $2^{\text {nd }}$ degree relatives and lifetime estrogen exposure duration $2 \mathrm{OR}$ adjusted for maternal age or paternal age (mutual parental age, categorical value) in addition to the variables in the model I tOR per 10 year

status and because individuals with higher socioeconomic status may tend to have children later. In this study, however, the education levels of study subjects (offspring) were not associated with paternal or maternal ages and education levels did not change the $\beta$ coefficient of paternal and maternal ages less than 15\%, thus education levels were not included in the final model. Moreover, controlling for subjects' education levels in narrower categories ( 5 categories; at or under elementary school, at middle school, at high school, at college, and at graduate school) did not significantly alter the breast cancer risk of paternal and maternal age. However, we could not adjust parental education since we had no information about parental education levels. Seventy-nine percent of cases and $91 \%$ of controls came from the same catchment areas (Seoul and suburbs). However, it did not indicate that the subjects came from the different study bases since the hospitals participated in the study were university hospitals which covered the patients in the whole country according to the current health delivery system in Korea [38].
Even if the catchment areas were different between cases and controls, this difference may push the association toward the null since more controls came from urban area where subjects had higher education levels which was associated with increased breast cancer risk. Second, possible unadjusting confounders from other risk factors for breast cancer in adult life $[39,40]$, but the risk of paternal and maternal ages on breast cancer remained same even after adjusting the established risk factors for breast cancer. However, other studies have mostly not found similar results and since small relative risks are involved and chance remains a likely explanation, the results of this moderately sized case-control study should be interpreted with extreme cautions.

\section{Conclusion}

This is the first and largest report about paternal and maternal ages and breast cancer in Asian women. These findings suggest that paternal age is associated with an increased risk of breast cancer in female offspring. How- 
Table 5: Summary of results from previous studies of parental ages and breast cancer development

\begin{tabular}{|c|c|c|c|c|c|c|c|c|c|c|}
\hline \multirow[t]{2}{*}{ Study } & \multirow[t]{2}{*}{ Country } & \multirow[t]{2}{*}{$\mathbf{N}$ (\# cases) } & \multirow[t]{2}{*}{ Age (yrs) } & \multirow{2}{*}{$\begin{array}{l}\text { Paternal age } \\
\text { (PA) }\end{array}$} & \multirow[t]{2}{*}{$\mathbf{R R}$} & \multirow{2}{*}{$\begin{array}{l}\text { Maternal age } \\
\text { (MA) }\end{array}$} & \multirow[t]{2}{*}{$\mathbf{R R}$} & \multicolumn{2}{|c|}{ Adjusting } & \multirow[t]{2}{*}{ Restricted } \\
\hline & & & & & & & & Mutually* & Covariates ${ }^{\dagger}$ & \\
\hline \multicolumn{11}{|l|}{ Cohort study } \\
\hline Colditz et al, |99| & US & II $8,309(1,976)$ & 3055 & $\geq 39$ vs. $<20$ & $0.9(0.56-1.45)$ & $\geq 39$ vs. $<20$ & $0.9(0.57-1.39)$ & YES & YES & - \\
\hline Zhang et al, 1995 & US & $2,662(149)$ & $29-62$ & $\geq 36$ vs. $<29$ & $0.8(0.5-1.4)$ & $26-31$ vs. $<26$ & $1.5(1.0-2.4)$ & - & YES & - \\
\hline Holmberg et al', 1995 & US & $384,769(1,967)$ & - & $\geq 45$ vs. $<20$ & $0.8(0.48-1.28)$ & $\geq 45$ vs. $<20$ & $1.3(0.85-1.98)$ & - & YES & - \\
\hline Hemminki et al, 1999 & Sweden & $\begin{array}{l}3,800,000 \\
(8,877)\end{array}$ & $15-53$ & $40-49$ vs. $<25$ & I.I (0.94-I.I8) & $40-49$ vs. $<20$ & I.I (0.9I-I.27) & YES & - & $\begin{array}{l}\text { PA in sporadic } \\
\text { cases }\end{array}$ \\
\hline Hilakivi-Clarke et al, $200 \mathrm{I}$ & Finland & $3,447(177)$ & - & - & - & - & NS & - & - & - \\
\hline \multirow[t]{2}{*}{ Study } & Country & Cases/controls & Age (yrs) & Paternal age (PA) & OR & $\begin{array}{l}\text { Maternal age } \\
\text { (MA) }\end{array}$ & OR & \multicolumn{2}{|c|}{ Adjusting } & Remark \\
\hline & & & & & & & & Mutually* & Covariates ${ }^{\dagger}$ & \\
\hline
\end{tabular}

\begin{tabular}{|c|c|c|c|c|c|c|c|c|c|c|}
\hline \multicolumn{11}{|l|}{ Case-control study } \\
\hline Standfast et al, 1967 & US & $229 / 229$ & $40-44$ & - & - & 29.1 vs. 28.2 & ${ }^{2} p<0.05$ & - & - & - \\
\hline Henderson et al, 1974 & US & $308 / 308$ & $<64$ & 31.5 vs. 30.7 & NS & 27.3 vs. 26.3 & $P<0.01$ & - & - & - \\
\hline Rothman et al, 1980 & International & $4339 / 12760$ & - & - & - & $35-39$ vs. $<20$ & 1.30 & - & YES & - \\
\hline Baron et al, 1984 & UK & $971 / 971$ & $\leq 50$ & - & - & $2 \mathrm{I}-25$ vs. $\leq 20$ & $1.4(0.92-2.18)$ & - & YES & - \\
\hline Le Marchand et al, 1988 & US & $|53 / 46|$ & $<45$ & $36-59$ vs. $19-26$ & I.4 (0.8I-2.4I) & $30-46$ vs. $23-26$ & $1.7(0.99-2.78)$ & - & - & Pts $<33$ yrs \\
\hline Janerich et al, 1989 & US & $801 / 2647$ & - & Per 10-yrs & $1.2(1.07-1.33)$ & Each 10-yrs & $1.2(1.09-1.4 \mid)$ & - & - & - \\
\hline Thompson et al, 1990 & US & $2492 / 2687$ & $20-54$ & - & - & $35-39$ vs. $<20$ & $1.5(1.10-1.93)$ & - & YES & parous \\
\hline Hsieh et al, 1991 & International & $927 / 2616$ & $\geq 35$ & - & - & Each 5-yrs & I.I (I.0I-I.10) & - & YES & postmenopause \\
\hline Ekbom et al, 1992 & Sweden & $458 / 1197$ & $\geq 35$ & - & - & Each 5-yrs & $1.0(0.92-1.12)$ & - & - & - \\
\hline Janerich et al, 1994 & US & $24 \mid 4 / 9138$ & - & $\geq 45$ vs. $<25$ & $1.0(0.76-1.28)$ & $\geq 40$ vs. $<20$ & I.I (0.87-I.37) & - & YES & - \\
\hline Sanderson et al, 1995 & US & $1147 / 1399$ & $21-45,50-64$ & - & - & $\geq 35$ vs. $<25$ & $\begin{array}{l}1.0(0.7-1.4), 1.0 \\
(0.7-1.5)\end{array}$ & - & - & - \\
\hline Ekbom et al, 1997 & Sweden & $1068 / 2727$ & - & - & - & Each 5-yrs & I.I (0.99-I.14) & - & - & - \\
\hline Newcomb et al, 1997 & US & $|253 /||2|$ & - & $\geq 40$ vs. $\leq 24$ & $0.9(0.68-1.24)$ & $\geq 40$ vs. $\leq 20$ & $0.9(0.62-1.37)$ & - & YES & - \\
\hline Weiss et al, 1997 & US & $2173 / 1990$ & $20-55$ & - & - & $\geq 35$ vs. $<20$ & $0.9(0.7-1.3)$ & - & YES & - \\
\hline Innes et al, 2000 & US & $484 / 2870$ & $14-37$ & $\geq 40$ vs. $25-29$ & $1.5(1.03-2.23)$ & $\geq 35$ vs. $20-24$ & $1.9(1.18-3.18)$ & YES & - & - \\
\hline Titus-Ernstoff et al, 2002 & US & $5629 / 5928$ & $50-79$ & - & - & $\geq 40$ vs. $25-29$ & $1.3(0.90-1.79)$ & - & - & postmenopause \\
\hline Mellemkjr et al, 2003 & Denmark & $881 / 3423$ & $<40$ & - & - & $\geq 30$ vs. $<25$ & I.I (0.90-1.36) & - & - & - \\
\hline Hodgson et al, 2004 & US & $280 / 236$ & $18-74$ & $35-56$ vs. $23-27$ & $1.5(0.7-3.2)$ & $\begin{array}{l}\geq 23-27 \text { vs. } 19- \\
22\end{array}$ & $3.5(2.0-5.9)$ & YES & - & $\begin{array}{l}\text { PA in African } \\
\text { American }\end{array}$ \\
\hline
\end{tabular}

* Adjusted for mutually parental age; †Adjusted for other risk factors of breast cancer risk including family history of breast cancer in $\left.\right|^{\text {st }}$ or $2^{\text {nd }}$ degree relatives and reproductive history; IMortality of breast cancer, relative hazard; 2 Paired $t$ test 
ever, further prospective study is needed to verify the present findings.

\section{Competing interests}

The author(s) declare that they have no competing interests.

\section{Authors' contributions}

J-YC conceived of the study, conducted data analysis, and drafted the manuscript. K-ML contributed to the design and management of data. SKP participated in data analysis and interpretation. D-YN, S-HA, and K-YY designed the study. DK conceived of and designed the study, obtaining funding and drafted the manuscript. All authors read and approved the final manuscript.

\section{Acknowledgements}

This research was supported in part by a grant No. 0I-PJI-PG3-219000006 of the 2001 Good Health R\&D Projects, Minister of Health and Welfare, South Korea..

\section{References}

I. Trichopoulos D: Hypothesis: does breast cancer originate in utero? Lancet 1990, 335(8695):939-940.

2. Crow JF: The origins, patterns and implications of human spontaneous mutation. Nat Rev Genet 2000, I ( I):40-47.

3. Wilcox AJ, Sandler DP, Everson RB: Using father's age to explore the role of germ cell mutation as a cause of human cancer. Int J Epidemiol I 988, I 7(2):469-47I.

4. Henderson BE, Powell D, Rosario I, Keys C, Hanisch R, Young M, Casagrande J, Gerkins V, Pike MC: An epidemiologic study of breast cancer. J Natl Cancer Inst 1974, 53(3):609-6I4.

5. Hodgson ME, Newman B, Millikan RC: Birthweight, parental age, birth order and breast cancer risk in African-American and white women: a population-based case-control study. Breast Cancer Res 2004, 6(6):R656-67.

6. Hsieh CC, Tzonou A, Trichopoulos D: Birth order and breast cancer risk. Cancer Causes Control I991, 2(2):95-98.

7. Innes K, Byers T, Schymura M: Birth characteristics and subsequent risk for breast cancer in very young women. $\mathrm{Am} J \mathrm{Epi}$ demiol 2000, I52(I2): II2I-II 28.

8. Janerich DT, Hayden CL, Thompson WD, Selenskas SL, Mettlin C: Epidemiologic evidence of perinatal influence in the etiology of adult cancers. J Clin Epidemiol I989, 42(2): I5 I- I57.

9. Le Marchand L, Kolonel LN, Myers BC, Mi MP: Birth characteristics of premenopausal women with breast cancer. $\mathrm{Br}$ J Cancer 1988, 57(4):437-439.

10. Standfast SJ: Birth characteristics of women dying from breast cancer. J Natl Cancer Inst 1967, 39(I):33-42.

II. Thompson WD, Janerich DT: Maternal age at birth and risk of breast cancer in daughters. Epidemiology I990, I(2): I0I-106.

12. Baron JA, Vessey M, McPherson K, Yeates D: Maternal age and breast cancer risk. J Natl Cancer Inst I 984, 72(6): I307-I 309.

13. Colditz GA, Willett WC, Stampfer MJ, Hennekens CH, Rosner B, Speizer FE: Parental age at birth and risk of breast cancer in daughters: a prospective study among US women. Cancer Causes Control 199I, 2(I):31-36.

14. Ekbom A, Hsieh CC, Lipworth L, Adami HQ, Trichopoulos D: Intrauterine environment and breast cancer risk in women: a population-based study. J Natl Cancer Inst 1997, 89(I):7I-76.

15. Ekbom A, Trichopoulos D, Adami HO, Hsieh CC, Lan SJ: Evidence of prenatal influences on breast cancer risk. Lancet 1992, 340(8826): $1015-1018$.

16. Hemminki K, Kyyronen P: Parental age and risk of sporadic and familial cancer in offspring: implications for germ cell mutagenesis. Epidemiology 1999, I0(6):747-75I.

17. Hilakivi-Clarke L, Forsen T, Eriksson JG, Luoto R, Tuomilehto J, Osmond C, Barker DJ: Tallness and overweight during child- hood have opposing effects on breast cancer risk. $\mathrm{Br} J$ Cancer 200I, 85(II): I680-I684.

18. Janerich DT, Thompson WD, Mineau GP: Maternal pattern of reproduction and risk of breast cancer in daughters: results from the Utah Population Database. J Natl Cancer Inst 1994, 86(2I): 1634-1639.

19. Mellemkjaer L, Olsen ML, Sorensen HT, Thulstrup AM, Olsen J, Olsen $\mathrm{JH}$ : Birth weight and risk of early-onset breast cancer (Denmark). Cancer Causes Control 2003, I 4(I):6I-64.

20. Newcomb PA, Trentham-Dietz A, Storer BE: Parental age in relation to risk of breast cancer. Cancer Epidemiol Biomarkers Prev 1997, 6(3): $151-154$.

21. Sanderson M, Williams MA, Malone KE, Stanford JL, Emanuel I, White $E$, Daling JR: Perinatal factors and risk of breast cancer. Epidemiology 1996, 7(I):34-37.

22. Titus-Ernstoff L, Egan KM, Newcomb PA, Ding J, Trentham-Dietz A, Greenberg ER, Baron JA, Trichopoulos D, Willett WC: Early life factors in relation to breast cancer risk in postmenopausal women. Cancer Epidemiol Biomarkers Prev 2002, I I (2):207-2I0.

23. Weiss HA, Potischman NA, Brinton LA, Brogan D, Coates RJ, Gammon MD, Malone KE, Schoenberg JB: Prenatal and perinatal risk factors for breast cancer in young women. Epidemiology 1997, 8(2): $|8|-\mid 87$.

24. Zhang Y, Cupples LA, Rosenberg L, Colton T, Kreger BE: Parental ages at birth in relation to a daughter's risk of breast cancer among female participants in the Framingham Study (United States). Cancer Causes Control 1995, 6( I):23-29.

25. Holmberg L, Ekbom A, Calle E, Mokdad A, Byers T: Parental age and breast cancer mortality. Epidemiology I 995, 6(4):425-427.

26. Office KNS: Annual report on the marriage and divorce statistics (based on vial registration). 2004.

27. Noh DY, Kim JS, Choe KJ, Lee MS, Ahn YO: A clinical and epidemiological review of benign breast disease. J Korean Surgical Society 1993, 44:797-808.

28. Choi JY, Lee KM, Park SK, Noh DY, Ahn SH, Chung HW, Han W, Kim JS, Shin SG, Jang IJ, Yoo KY, Hirvonen A, Kang D: Genetic polymorphisms of SULT IAI and SULT IEI and the risk and survival of breast cancer. Cancer Epidemiol Biomarkers Prev 2005, I4(5): 1090-1095.

29. Korea Institute for Health \& Social Affairs: Survey on the national fertility, family health and welfare (2003). 2004.

30. Rothman KJ, MacMahon B, Lin TM, Lowe CR, Mirra AP, Ravnihar B, Salber EJ, Trichopoulos D, Yuasa S: Maternal age and birth rank of women with breast cancer. J Natl Cancer Inst 1980, 65(4):719-722

31. Kaijser M, Granath F, Jacobsen G, Cnattingius S, Ekbom A: Maternal pregnancy estriol levels in relation to anamnestic and fetal anthropometric data. Epidemiology 2000, I I (3):3 I5-3I9.

32. Panagiotopoulou K, Katsouyanni K, Petridou E, Garas Y, Tzonou A, Trichopoulos D: Maternal age, parity, and pregnancy estrogens. Cancer Causes Control 1990, I(2): I 19-124.

33. Potischman N, Troisi R: In-utero and early life exposures in relation to risk of breast cancer. Cancer Causes Control 1999, I 0(6):56 I-573.

34. Shibata A, Minn AY: Perinatal sex hormones and risk of breast and prostate cancers in adulthood. Epidemiol Rev 2000, 22(2):239-248.

35. Jung A, Schuppe HC, Schill WB: Are children of older fathers at risk for genetic disorders? Andrologia 2003, 35(4): | 91 - 199.

36. Brinkworth $\mathrm{MH}$ : Paternal transmission of genetic damage: findings in animals and humans. Int J Androl 2000, 23(3): 123-135.

37. Ashwood-Smith MJ, Edwards RG: DNA repair by oocytes. Mol Hum Reprod 1996, 2(I):46-5I.

38. Nam SM: A study on choosing the medical care provider. In School of Public Health Volume MS. Seoul, Seoul National University; 2001 .

39. Baik I, Becker PS, DeVito WJ, Lagiou P, Ballen K, Quesenberry PJ, Hsieh CC: Stem cells and prenatal origin of breast cancer. Cancer Causes Control 2004, I 5(5):5 17-530.

40. Joseph KS, Kramer MS: Review of the evidence on fetal and early childhood antecedents of adult chronic disease. Epidemiol Rev 1996, I8(2): I58-174. 


\section{Pre-publication history}

The pre-publication history for this paper can be accessed here:

http://www.biomedcentral.com/1471-2407/5/143/pre pub

Publish with Bio Med Central and every scientist can read your work free of charge

"BioMed Central will be the most significant development for disseminating the results of biomedical research in our lifetime. " Sir Paul Nurse, Cancer Research UK

Your research papers will be:

- available free of charge to the entire biomedical community

- peer reviewed and published immediately upon acceptance

- cited in PubMed and archived on PubMed Central

- yours - you keep the copyright 